Working Paper 9209

CAPITAL FORBEARANCE AND THRIFTS:

AN EX POST EXAMINATION OF REGULATORY GAMBLING

by Ramon P. DeGennaro and James B. Thomson

Ramon P. DeGennaro is an assistant professor of finance at the University of Tennessee,

Knoxville, and James B. Thomson is an assistant vice president and economist at the Federal

Reserve Bank of Cleveland. The authors thank Philip Bartholomew, Michael Bradley, Peter Elmer, Robert Grohol, Edward Kane, George Kaufman, Shirley Love, J. Huston McCulloch, Patricia Rudolph, and Steve Watson for helpful comments and suggestions. They are also grateful to Christopher Pike and Joseph Pilko for outstanding research support.

Working papers of the Federal Reserve Bank of Cleveland are preliminary materials circulated to stimulate discussion and critical comment. The views stated herein are those of the authors and not necessarily those of the Federal Reserve Bank of Cleveland or of the Board of Governors of the Federal Reserve System. 


\begin{abstract}
This paper estimates the losses embedded in the capital positions of the 996 FSLIC-insured savings and loan institutions that did not meet capital standards at the end of the 1970 s. We compare the estimated cost of resolving the insolvencies of these institutions at the end of the 1970s with the actual failure-resolution costs for those that were closed by July 31,1992 , and the projected resolution costs for the remaining thrifts that are likely to be closed. Our results show that even when one considers only the direct costs associated with delayed closure of economically failed thrifts, these costs significantly exceed reasonable estimates of the cost of prompt failure resolution.
\end{abstract}




\section{Capital Forbearance and Thrifts: An Ex Post Examination of Regulatory Gambling}

The Federal Reserve System's October 1979 commitment to reduce inflation resulted in historically high interest rates in the early 1980s. The three-month Treasury bill rate, which had stood at 6.49 percent in January 1980 , rose to a peak of 16.30 percent in May 1981 and returned to the single-digit range by August 1982 (see White [1991, table 5-1]). Although this policy successfully lowered the inflation rate and set the stage for lower interest rates throughout the 1980s, it had a devastating impact on savings and loan (thrift) institutions. The industry's portfolio, which consisted of long-term fixed-rate loans (principally mortgages) financed with short-term liabilities (principally deposits), had a negative duration gap that made it extremely vulnerable to sudden, unexpected increases in interest rates. For many thrifts, the surge in interest rates in the early 1980 s was the final blow to a capital position that had been gradually eroded by inflation during the latter half of the 1970s. By 1982, unbooked capital losses on thrifts' balance sheets not only exceeded book equity at a large number of institutions, but also surpassed the explicit resources of the Federal Savings and Loan Insurance Corporation's (FSLIC) deposit insurance fund.

From the late 1970 s through mid-1989, regulators, gambling that unexpectedly lower interest rates would restore thrift institutions to health, progressed through several stages in their attempts to push the ultimate resolution of the FSLIC's insolvency into the future. They dramatically reduced the required capital ratio and even permitted a number of thrifts deemed 
insolvent under regulatory accounting principles (RAP) to continue to operate.'

RAP is a historical cost accounting system that measures solvency as the difference between the book value of assets and liabilities. No adjustment is made to account for unbooked losses or for market-related changes in the value of assets and liabilities. Marketbased measures of solvency explicitly incorporate these market-related changes in values and therefore give a more accurate measure of the true condition of the firm. In the case of thrifts, historical cost accounting significantly overstated the true solvency of thrifts in the early 1980 s because of substantial unbooked losses on their mortgage portfolios due to a dramatic increase in market interest rates. ${ }^{2}$

The official response to the insolvency of the thrift industry and the FSLIC can be characterized as a bet made by policymakers that by forestalling the ultimate resolution of the "crisis," the bill presented to taxpayers would be less. In this paper, we explicitly determine whether taxpayers won that bet by analyzing the direct costs of regulatory forbearance, specifically those directly related to resolving the insolvency of FSLIC-insured thrifts. Because we ignore important secondary costs associated with the incentive effects of forbearance and spillover effects, our estimate of the cost of forbearance is likely to significantly understate the true cost.

${ }^{1}$ A 1987 U.S. General Accounting Office study shows that in September 1986, 219 RAP-insolvent FSLIC-insured thrifts were in operation and another 250 had RAP net worth of less than 0.5 percent (see U. S. GAO [1987a, table 1.5]).

2 RAP net worth is one of three measures of solvency based on historical cost. The other two are generally accepted accounting principles (GAAP) net worth and tangible net worth (TNW). While there is a great deal of divergence among RAP net worth, GAAP net worth, and TNW over the time period studied, these three book-value measures of solvency give a very similar picture of the thrift industry in December 1979 . RAP net worth, however, became an even less-reliable measure of solvency over the 1980 s as policymakers artificially augmented the measure. 
Did taxpayers win or lose the gamble made by policymakers? By delaying official recognition of the insolvency of a larger number of thrifts (and the consequent insolvency of the FSLIC), were the total losses reduced? To determine this, we compute marked-to-market estimates of the embedded losses on the books of FSLIC-insured thrifts that failed to meet accounting-based minimum regulatory capital standards on December 31,1979 . These embedded losses, which are estimates of prompt resolution costs, are then compared to the discounted present value of future resolution costs associated with the subset of sample institutions that have been closed or are likely to be closed by the thrift regulatory agency. We find that taxpayers lost the forbearance bet, as the present value of future closure costs is more than double the cost of prompt intervention.

The paper is organized as follows. Section I presents forbearance as a regulatory gamble. Section II sets up the null and alternative hypothesis and the sample selection criteria, and section III presents the empirical methods and results. Conclusions and policy recommendations appear in section IV.

\section{Forbearance as a Regulatory Gamble}

The initial policy response to the insolvency of the thrift industry was capital forbearance. Both the Deposit Institutions Deregulation and Monetary Control Act of 1980 (DIDMCA) and the Garn-St Germain Act of 1982 aimed at providing relief for the thrift industry. ${ }^{3}$ These

\footnotetext{
${ }^{3}$ DIDMCA was the first in a series of actions taken by legislators and regulators to grant thrifts new investment powers. It authorized federally chartered S\&Ls to invest up to 20 percent of their assets in corporate bonds and consumer loans and extended their authority to make construction or acquisition loans. The portfolio investment limits for commercial and consumer loans were raised further by the Gam-St Germain Act.
} 
two pieces of legislation combined with regulatory efforts to cause a dramatic reduction in thrift capital requirements and the introduction of RAP to mask the true insolvency of the industry. ${ }^{4}$ Policymakers, reasoning that unexpectedly lower rates or more-diversified assets would restore these institutions to health, chose to forbear and took actions to cover up emerging problems in the industry. This interest-rate bet was not symmetric, however, as the prepayment option held by mortgagors made interest-rate declines less profitable for thrifts than increases would be costly.

Capital forbearance was (and is) attractive to policymakers for three reasons. First, as Kane (1989a, ch. 4; 1989b) argues, the classic principal-agent conflict described by Jensen and Meckling (1976) exists in public agencies. In other words, bank and thrift regulatory agencies are self-maximizing bureaucracies whose primary task may be conceived as acting as the agent for taxpayers (the government's principal) to ensure a safe and sound banking system and to minimize their loss exposure. Regulators also must cater to a political clientele who are intermediate or competing principals. Furthermore, regulators are sometimes motivated by their own self-interest, which may not coincide with the interests of taxpayers. These political pressures and self-interest considerations create socially perverse incentives that make forbearance an appealing alternative to dealing with emerging problems both early

\footnotetext{
${ }^{4}$ Capital forbearance had two components. First, regulators systematically lowered the actual requirement from 5 to 3 percent of assets. In November 1980, the Federal Home Loan Bank Board (FHLBB) both reduced thrifts' explicit capital requirement from approximately 5 to about 4 percent and provided for a "qualifying balance deduction" that effectively lowered the requirement even more. In January 1982, the capital requirement was further reduced to 3 percent. After 1987, thrift regulators largely ignored capital standards. Second, policymakers adopted regulatory accounting principles that represented a departure from GAAP accounting. In November 1981, the FHLBB accepted net-worth certificates from thrifts with less than 3 percent net worth as capital in exchange for FSLIC promissory notes, with face value guaranteed by the FSLIC. In July 1982, thrift regulators permitted goodwill to be amortized over a 40-year period and allowed income from unbooked gains to be realized in as little as five years. Finally, in November 1982, the FHLBB began to include "appraised equity capital" in its calculations of regulatory net worth. For a more complete accounting of forbearances, see Barth and Bradley (1989), Kane (1989a), and White (1991). 
and forcefully. In sum, Kane's analysis suggests that forbearance might be an attractive bet for bureaucratic-minded managers of financial services regulatory agencies and their political constituencies even if it is not a fair bet for taxpayers.

In the early 1980 s, forbearance also became an attractive alternative for policymakers because the unbooked losses on the balance sheets of thrifts, and hence of the FSLIC, were initially the result of unexpectedly high interest rates at that time. Policymakers hoped that if interest rates returned to lower levels, many of the nonviable thrifts would recover. Such an interest-rate bet is a form of regulatory gambling (Kane [1989a, ch. 5]).

The third reason for forbearance's appeal to policymakers is that the FSLIC did not have the explicit resources to deal with the losses. As Kane (1986), Demirgüc-Kunt (1991), and Thomson (1992) show, liquidity constraints reduce the ability of regulators to close insolvent institutions. Given the unwillingness of the President to request and Congress to allocate sufficient funds to recapitalize the FSLIC in the early 1980 s, thrift regulators could not have moved decisively against a large number of insolvent savings and loans, even if it had been in their self-interest to do so.

Finally, in August 1989, Congress passed the Financial Institutions Reform, Recovery, and Enforcement Act (FIRREA) to provide money and a regulatory structure for dealing with and resolving the crisis. ${ }^{5}$ The initial estimate of the cost of disposing of some 500 hopelessly insolvent thrifts was projected to be $\$ 124$ billion (Pauley [1989]), but it is now clear that the true cost of the thrift debacle will exceed \$200 billion.

\footnotetext{
${ }^{5}$ Unfortunately, this landmark piece of legislation failed to provide sufficient funds to resolve the FSLIC insolvency. It also created a public salvage mechanism, known as the Resolution Trust Corporation (RTC), with an implicit mandate to jointly minimize the financial costs and the political costs associated with the resolution of the thrift insurance mess (see Kane [1990] and Pike and Thomson [1991]).
} 
Although the price tag for resolving the insolvency of FSLIC's insurance fund is staggering, it has not been demonstrated that taxpayers lost the gamble. Kane $(1985$, ch. 4) estimates that the embedded losses in the FSLIC fund were in excess of $\$ 100$ billion as early as $1982 .^{6}$ On the other hand, previous studies of thrifts that were either GAAP insolvent or undercapitalized in the early 1980s found that, despite the dramatic decrease in interest rates after 1982, the majority of thrifts receiving capital forbearance failed to recover later.

The first study, done by the U.S. General Accounting Office (U.S. GAO [1987a]), covers December 1982 through September 1986. The sample consists of 222 firms that were insolvent according to GAAP net worth in December 1982. By September 1986, 77 of these thrifts had merged, were closed, or required FSLIC assistance to remain open. Of the surviving firms, 80 remained GAAP insolvent and 65 regained GAAP solvency. Only 25 of the GAAP-solvent firms had GAAP net-worth-to-asset ratios above 3 percent. $^{7}$

Rudolph (1989) looks at the 237 thrifts that were GAAP insolvent at year-end 1982. Tracing these firms into the future, she finds that by the close of 1987,69 of these firms had merged and another 23 were closed or required FSLIC assistance to remain open. Of the 145 thrifts still in existence in December 1987, 77 remained GAAP insolvent and 68 regained GAAP solvency.

DeGrennaro, Lang, and Thomson (1991) study the differences in operating strategies

\footnotetext{
${ }^{6}$ Kane's estimate was recently validated by former FHLBB Chairman Richard Pratt (1990), who testified before Congress that by 1982 , the FSLIC insurance reserve was a negative $\$ 100$ billion.

${ }^{7} \mathrm{GAO}$ also examined an additional sample of 916 thrifts that had GAAP net-worth-to-asset ratios between 0 and 3 percent in December 1982. By September 1986, 170 of these marginally book-solvent firms had merged, were closed, or required FSLIC assistance to remain open. Of those thrifts that were still operating by September 1986, 280 remained marginally solvent by GAAP standards and 186 had become GAAP insolvent.
} 
between troubled thrifts that recover and those that do not. Their sample consists of the 300 largest thrifts that had a GAAP net-worth-to-assets ratio of less than 5 percent at year-end 1979. By December 1989, 75 of the thrifts in the sample were closed or required FSLIC assistance to remain open, 90 had merged into another thrift, and 63 failed to meet FIRREA capital standards (ratios of 3 percent GAAP net worth to assets and 1.5 percent tangible net worth to assets). They further note that only 39 of the thrifts in their sample had GAAP networth-to-asset ratios above 5 percent by the end of 1989 .

Although these studies show that very few capital-deficient thrifts returned to health and therefore support the hypothesis that forbearance was a losing proposition for taxpayers, none of them attempts to compute the attendant costs. That is, none of these studies compares the cost of taking action against undercapitalized thrifts at the beginning of the 1980 s with the ultimate cost of closing the subset of forbearance thrifts that failed to recover.

To date, the Congressional Budget Office has produced one of the few analyses of the direct costs of forbearance (Bartholomew [1991]). This study examines 1,130 thrifts that were resolved (at a cost to the FSLIC or the RTC) between January 1, 1980 and December 31,1990 or that were projected to be resolved during 1991. The actual resolution cost for each institution at the time it was closed (and then projected costs for 1991 resolutions) is compared with the estimated cost associated with closing the thrift when its tangible net worth (TNW) became negative. The difference between these two costs, adjusted for inflation, is Bartholomew's estimate of the cost of forbearance. This study suggests that prompt closure of thrifts when they became TNW insolvent could have saved taxpayers as much as $\$ 66$ billion (in 1990 dollars). 
Our study is similar in spirit to Bartholomew's, in that we also make comparisons between the estimated resolution cost at the time a thrift is closed and the projected cost of regulatory intervention at an earlier date. However, there are a number of important differences. First, instead of defining forbearance as the failure of regulators to close thrifts when they become TNW insolvent, we define it as the failure of policymakers to enforce capital standards. Thus, our initial sample consists of the 996 FSLIC-insured thrifts that failed to meet capital standards in December $1979 .{ }^{8}$ While both analyses consider the cost of delayed closure, our study is focused on the forbearance bet made by policymakers at the end of the 1970s.

The second difference between our study and Bartholomew's is that we set up an ex ante forbearance bet, rather than an ex post bet. We include all book-capital-deficient thrifts as of December 31,1979, whereas Bartholomew looks at all institutions that were resolved (at a cost to the FSLIC or RTC) from 1980 to 1990 and at those thrifts likely to be resolved in 1991. In other words, the Bartholomew study is limited to failed institutions, while ours includes all capital-deficient thrifts on the event date. This removes an important source of bias in the Bartholomew study. By omitting the thrifts that became TNW insolvent but subsequently recovered, Bartholomew understates the true costs of prompt resolution and therefore may overstate the cost of forbearance.

On the other hand, omitting insolvent thrifts that subsequently recovered may also

\footnotetext{
${ }^{8}$ Our sample screen initially identified 998 thrifts that failed to meet capital standards in December 1979. However, upon closer inspection, we identified two thrifts in the sample that were newly chartered in 1979. Regulators would be unlikely to allow a new thrift to open that did not meet capital standards; thus, we assumed that our sample screen misidentified these institutions and removed them from the sample. Note that one of these thrifts was closed in September 1989 and the other was still operating as an independent thrift as of July 31, 1992.
} 
introduce a downward bias in the measured cost of forbearance. Taxpayers bore all of the downside loss from forbearance, but did not share in any of the upside gains past the point where the thrift had zero liquidation value. These upside gains would have accrued to the government had it nationalized the institution and later sold it. By choosing forbearance, the government essentially nationalized the downside risk and privatized the upside gains. This bias is also present in our study.

A third way our study differs from Bartholomew's is in our method for determining unbooked losses in thrift portfolios at the event date. We use Kane-Yu's (Kane [1991], Kane and $\mathrm{Yu}$ [1992]) marked-to-market procedure to compute the embedded losses on the balance sheets of our sample thrifts. In contrast, Bartholomew calculates the cost of prompt resolution by assuming the underlying sources of the embedded losses are the same on the event date and on the resolution date. This is an important untested maintained hypothesis, which Barth, Bartholomew, and Bradley (1990), Cole, McKenzie, and White (1991), DeGennaro, Lang, and Thomson (1991), and White (1991) imply does not hold. In fact, both White and Barth, Bartholomew, and Bradley suggest the presence of as many as three different regimes during the sample period used in both this and the Bartholomew study. Finally, Bartholomew's method of adjusting the spread between the estimated prompt resolution cost and the future resolution cost is not fully adjusted for inflation, nor does it consider the time value of money. We fully account for both effects, however, by using the discounted present value of future resolution costs in constructing our cost of forbearance. ${ }^{9}$

\footnotetext{
${ }^{9}$ We do not, however, want to minimize the importance of Bartholomew's study. His results represent an additional piece of evidence supporting our null hypothesis that the forbearance bet was a losing proposition for taxpayers.
} 


\section{Defining Forbearance}

Webster's defines forbearance as "a refraining from the enforcement of something (as a debt, right, or obligation) that is due." ${ }^{10}$ In this paper, forbearance is narrowly defined as the decision by regulators and policymakers not to enforce capital standards at the end of the 1970s. Therefore, for our purposes a forbearance thrift is one that did not meet the accounting-based regulatory capital test on December 31, 1979.

Of the 4,038 FSLIC-insured thrifts in existence in 1979, 996 failed to meet the minimum regulatory capital standard. This was an accounting-based standard requiring thrifts to meet two capital tests: a federal insurance reserve test, which essentially was a maximum leveraging test; and an asset composition test, which was in essence a risk-based capital test. Both of these capital tests are described in appendix A. The fact that nearly 25 percent of all FSLIC-insured thrifts failed to meet book-value-based regulatory capital standards at the end of 1979 is startling, because these standards do not take into account the interest-rate-related capital losses on thrift balance sheets at that time. As we show later, the size of the unbooked losses on the balance sheets of these 996 institutions suggests that a high percentage of the thrifts that met the capital standards on December 31, 1979 were marketvalue insolvent.

In constructing our final sample, we make the additional assumption that thrift regulators could have acted either to force the recapitalization of, to close or merge, or to take into government conservatorship (nationalize) all 996 capital-deficient thrifts by the end of 1980. Therefore, we exclude from the sample the nine thrifts that were closed in 1980 and

\footnotetext{
${ }^{10}$ See Webster's Ninth New Collegiate Dictionary, Springfield, MA: Merriam-Webster Inc., 1986, p. 482.
} 
the 35 that merged into another institution that year. This leaves us with a sample of 952 forbearance thrifts, which we use to test the following hypotheses:

H0: Taxpayers lost the forbearance bet. The present value of future losses associated with insolvency resolution of the 952 forbearance thrifts exceeds the estimated cost of prompt resolution in 1980 .

H1: Taxpayers won the forbearance bet. The present value of future resolution costs associated with the 952 forbearance thrifts that fail or are projected to fail is less than the estimated cost associated with prompt resolution.

Note that by focusing our test on the direct costs associated with the resolution of the forbearance thrifts, we are ignoring important secondary costs. Specifically, the adoption of capital forbearance policies increased the risk-taking incentives for all insured depository institutions. This, in turn, led to a misallocation of resources and deadweight losses to the economy. Hendershott and Kane (1992) argue that thrift forbearance was a major contributing factor in the real estate construction boom, estimating the deadweight losses in this market to be between $\$ 124$ billion and $\$ 150$ billion. The Congressional Budget Office (1992) calculates that the misallocation of resources associated with the thrift insurance mess produced a deadweight loss of $\$ 200$ billion (in 1990 dollars) in foregone GNP from 1981 through 1990, and that the total loss in potential GNP by the year 2000 will be on the order of $\$ 500$ billion (in 1990 dollars).

Another indirect cost of thrift forbearance was the destabilization of the depository institutions industry. The profitability of the healthy segment of this industry was reduced as insolvent thrifts, in a desperate attempt to regain solvency, bid down lending rates and bid up deposit rates to unsustainable levels. This spillover effect has been described by Kane (1989a, pp. 4-5), who refers to the insolvent but open thrifts as "institutional zombies." Finally, 
Shoven, Smart, and Waldfogel (1992) link the historically high real interest rates to zombie thrift behavior in deposit markets. Federally insured certificates of deposit and Treasury bills are close substitutes (made even closer substitutes by forbearance). As zombie thrifts bid up the rates offered on quasi-government debt, they drove up the required rate of return on official U.S. Treasury debt. Shoven, Smart, and Waldfogel suggest that the thrift insurance mess may have increased the borrowing costs of the U.S. Treasury by as much as $\$ 100$ billion (in 1990 dollars) per year by the end of the 1980 s.

In any event, although the above indirect costs of forbearance are not mutually exclusive and are difficult to quantify, they are real and economically significant. Therefore, our focus on the direct costs of forbearance will cause us to understate the true costs of forbearance and bias us against accepting the null hypothesis.

\section{Measuring the Cost of Forbearance}

To measure the cost of forbearance, we need an estimate of the costs of prompt intervention during 1980 and a present-value estimate of the actual or projected future costs of resolving those forbearance thrifts that did not recover by December 31,1991 .

$$
\text { Forbearance }=\sum_{i=1}^{952} \operatorname{Max}\left(0,-1.0 * M V 79_{i}\right)-\sum_{i=1}^{952} \frac{1}{\left(1-I_{t}\right)^{2}} \operatorname{Max}\left(0, \operatorname{RESCOST}_{1, t}\right)
$$

In equation (1), MV79 is thrift i's marked-to-market value of equity adjusted for fixed costs of bankruptcy, and RESCOST $\mathrm{h}_{\mathrm{h}, \mathrm{i}}$ is the actual estimated resolution cost or projected resolution 
cost at time $t$ associated with closing thrift $i . "$ For example, if the thrift was closed in $1986, t$ equals $6(t=86-80)$. For insolvent but still operating (zombie) thrifts, the closure year is assumed to be 1992 and, therefore, $t=12$. Finally, $r_{t}$ is the appropriate one-period discount factor corresponding to period $t$.

\section{A. Method for Constructing Estimates of Prompt Resolution Costs}

To estimate the embedded losses on the balance sheets of forbearance thrifts, we use the synthetic market value accounting method of Kane-Yu (1992). Kane-Yu construct market values for thrift asset and liability subportfolios by comparing realized rates of return on each subportfolio to an alternative market rate of return. Their basic formula is

$$
M V_{X}=B V_{X}\left(\frac{R}{I}\right) \frac{1-(1+I)^{-m}}{1-(1+R)^{-m}}
$$

where $M V_{x}$ and $B V_{x}$ are the market and book value of assets (liabilities) at time 0 in subportfolio $x ; R$ and $r$ are the rate of return on the subportfolio and equivalent market rate of return, respectively; and $m$ is the number of periods until the subportfolio matures. Equation (2) assumes the subportfolio is an annuity, with $\mathrm{m}$ future payments and no prepayment.

\footnotetext{
"The actual resolution cost is really an estimate of the losses to the FSLIC or RTC at the time the thrift is closed. Ultimate resolution costs may be higher or lower depending on the final salvage value of the thrift's assets retained or guaranteed by the FSLIC or RTC. For example, the FDIC's August 1990 estimate of the present-value cost of the 1988 resolutions and stabilizations was $\$ 47$ billion, as opposed to the FHLBB's 1988 estimate of $\$ 38$ billion (Barth [1991, p. 31]). The cost to taxpayers could also be higher than the cost to the FSLIC (for cases before 1989) if the FSLIC transferred tax-loss credits to the acquirer at the time of resolution. Moreover, Kane's (1989a, 1989b) principal-agent model of financial services regulatory behavior suggests that unless these regulators are "faithful public servants," the estimated resolution cost will be a low-biased estimate of the true cost.
} 
When $r>R(r<R)$, a positive probability of prepayment will cause equation (2) to understate (overstate) the market value of the subportfolio.

We define the cost of prompt resolution as the minimum of synthetic net worth (less fixed resolution costs) and zero. As seen in equation (3) below, SNW is constructed by adding (subtracting) the difference between the market and book values of the $m$ asset (n liability) subportfolios from balance sheet TNW:

$$
S N W=T N W+\sum_{g=1}^{a}\left(M V_{g}-B V_{g}\right)-\sum_{j=1}^{1}\left(M V_{j}-B V_{j}\right) .
$$

Using data from the December 31, 1979 Thrift Financial Report, we divide thrift balance sheets into net worth, four liability subportfolios, and eight asset subportfolios (see table I and appendix B). Using equation (2), we construct synthetic market values for all of the asset and liability subportfolios, except for all other assets and other liabilities, for which we assume BV equals MV.

To calculate synthetic market values for each asset and liability subportfolio, we construct measures of book assets (liabilities), book return on assets (liabilities), and a market rate of return on an asset or portfolio with similar risk characteristics. The level of aggregation within each subportfolio is determined by the availability of information in the Thrift Financial Report for computing book asset returns, and on the availability of an equivalent market rate of return.

Ideally, we would also subdivide each subportfolio into a number of maturity buckets for determining $\mathrm{m}$ in equation (2) and thereby improve the precision of the synthetic market- 
value estimate. Unfortunately, thrifts did not report this information until 1984. In many cases, however, we have information on the average life of the assets in the subportfolios and, therefore, we have a good estimate of $\mathrm{m}$. In the few cases for which information on $\mathrm{m}$ is not available, the size of the subportfolio relative to total assets is typically small. Moreover, the sensitivity of the results to the choice of $\mathrm{m}$ is easily explored.

Finally, with the exception of the real estate subportfolio, BV for each subportfolio consists of assets net of slow loans (nonperforming loans) and net of loans in process. By netting slow loans and loans in process from the subportfolios, we reduce those subportfolios to assets that are currently accruing interest. Because subportfolio assets enter into the denominator of the book return on assets, $R$, the use of net rather than gross assets removes an important downward bias in $\mathrm{R}$, and therefore in MV. The unbooked loss associated with slow loans is separately deducted from TNW in arriving at SNW.

Subportfolio returns are calculated by dividing income (interest, dividends, fees, and accrued interest receivable) by net assets. We add implicit interest earned on escrow accounts to mortgage income in the calculation of the return on the mortgage portfolios. Implicit interest is assumed to accrue to escrow accounts every three months at the three-month CD rate. ${ }^{12}$ In addition, in cases in which accrued interest receivable is reported on an aggregate basis, as is true for mortgages and mortgage-backed securities, we prorate it across subportfolios according to relative assets. In the case of mortgage servicing rights, we compute the return on assets as the difference between the income earned per dollar of

\footnotetext{
12 The annual three-month CD rate on December 1979 was 13.43 percent. See table 1.36, "Interest Rates: Money and Capital Markets," Federal Reserve Bulletin (March 1980), p. A27.
} 
mortgages serviced (which includes implicit interest on escrow accounts related to these mortgages) and the cost of servicing the mortgages, which we assume is 25 basis points on the outstanding balance of mortgages serviced. ${ }^{13}$ Net subportfolio assets and the book return on assets for each subportfolio can be found in table II. The alternative market rates of return for each subportfolio are either published rates of return for December 1979 or rates of return constructed using data from December 1979. A summary of these returns and their sources appears in appendix $\mathrm{C}$.

We use equation (2) to construct synthetic market values for the subportfolios, with the exception of real estate, service corporation subsidiaries, FHLBB advances (< 1 year), borrowings (other borrowed money $<1$ year), all other assets, and other liabilities. For the real estate subportfolio, we assume that assets were booked at market value; because of data constraints, we assume they were held an average of two years. ${ }^{14}$ For real estate, MV equals BV multiplied by one plus the average annual change in Russell's national real estate price index from White (1991, table 6-10). ${ }^{15}$ For service corporation subsidiaries, MV is the value of the following perpetuity: service corporation subsidiary net income divided by the 1979 annual return on Standard \& Poor's 500 stock index. If either the net income figure or the

\footnotetext{
${ }^{13}$ Kane-Yu assume the cost of mortgage servicing is 20 basis points. Other sources suggest that the fees thrifts charge for mortgage servicing range from 25 to 44 basis points on the outstanding mortgage balance. See Secondary Mortgage Markets 6 (Winter 1989/90).

${ }^{14}$ Kane-Yu assume two years for real estate held for investment and four years for other real estate owned. While the two-year assumption is ad hoc, it derives from necessity, as our data source on real estate prices begins at the end of 1977 .

${ }^{15}$ Recent work by Hendershott and Kane (1992) suggests that from 1982 to 1991 , the Russell index was severely biased upward. This suggests that our use of the Russell index from 1977 to 1979 may lead us to overstate the market value of thrift real estate holdings. However, given the relatively small share of thrift assets in real estate in December 1979 (0.4 percent of total assets), this potential bias will not qualitatively affect the results.
} 
thrift's investment in the service corporation subsidiary is negative, we assume that $\mathrm{MV}$ equals BV. For FHLBB advances (<1 year) and borrowings (other borrowed money < 1 year), MV is computed by discounting the principal plus interest of these parts of the FHILBB advances and borrowings subportfolios using the six-month secondary market $\mathrm{CD}$ rate. Finally, as noted earlier, we assume MV equals BV for all other assets and for other liabilities. The equations used to construct the MVs for each subportfolio are reported in appendix $\mathbf{D}$.

\section{B. Estimates of Prompt Resolution Costs}

Table III presents the estimates of unbooked losses or gains in the subportfolios (BV minus MV) for the 952 forbearance thrifts in December 1979. On average, unbooked losses on the mortgage portfolio are 1.45 times TNW, 6.68 percent of subportfolio assets, and 60 percent of total unbooked losses. Service corporation subsidiaries, mortgage-backed securities, and other loan subportfolios have higher market-to-book discounts (or pseudo default rates) -- 40.10 percent, 14.32 percent, and 10.59 percent, respectively. However, since these subportfolios combined account for only 7.4 percent of total assets, as opposed to 78 percent for mortgages, the total unbooked losses on these subportfolios are less than 60 percent of TNW.

On the liability side, unbooked gains on fixed-rate deposits are 82.04 percent of TNW and are eight times the size (in absolute value) of the unbooked gains of FHIBB advances and borrowings combined. Overall, unbooked gains and losses for sample thrifts are 2.39 times TNW.

As seen in table IV, total unbooked losses in December 1979 exceeded the forbearance thrift's tangible net worth by $\$ 7.44$ billion. Synthetic net worth as a percent of total assets 
(SNWA) is -5.63 percent for the sample. This market-based measure of solvency gives a much different and more realistic picture of the condition of the thrift industry in 1979 than do book measures of net worth.

Like other published estimates of market net worth for banks and thrifts, our SNW measure is sensitive to particular assumptions. While the choices of alternative market rates of return are clear, some of the maturity assumptions are ad hoc. Thus, we investigated the sensitivity of the synthetic net worth estimate to the maturity assumptions for all subportfolios for which the ratio of subportfolio assets to total assets exceeds 5 percent. ${ }^{16}$ Two asset subportfolios and one liability subportfolio exceeded this threshold: mortgages (78.48 percent), investments (6.30 percent), and fixed-rate deposits (60.85 percent).

For mortgages, we reconstructed synthetic market values using 10 years and 14 years of maturity instead of 12 . In addition to the five-year maturity assumed in computing the numbers in table III, we computed synthetic market values for the investment subportfolio using two- and 10-year maturity assumptions. Finally, we computed synthetic net worth for fixed-rate deposits assuming maturities of one year and four years. Given these maturity assumptions, the smallest $\mathrm{SNW}$ we can construct is when $\mathrm{m}=(14,2,4)$, and the largest $\mathrm{SNW}$ is arrived at when $m=(10,10,1)$ for mortgages, investments, and fixed-rate deposits, respectively. Under these extreme combinations, the SNW (SNWA) for the sample ranges

\footnotetext{
${ }^{16}$ FHLBB advances are divided into long- and short-term advances for purposes of synthetic market value accounting. While total advances fund 8.52 percent of the average forbearance thrift's assets, long-term and short-term advances are used to fund 4.95 and 3.57 percent of assets, respectively. Therefore, neither portion of the subportfolio itself meets our 5 percent of assets threshold. Furthermore, the six-month maturity assumption for short-term FHLBB advances is reasonable, and alternative values make little difference. The 3.47-year maturity assumed for long-term advances is the industry average published by the FHLBB (see appendix C).
} 
from a low of $-\$ 13.81$ billion $(-9.90$ percent $)$ to a high of $-\$ 4.90$ billion $\left(-3.51\right.$ percent) ${ }^{17}$

To arrive at the cost of prompt resolution (that is, the cost of closing these thrifts in 1980), we need to make some adjustments to the SNW estimate. First, we must adjust for the value of the fixed assets of the thrift (such as buildings, fixtures, equipment) that may be sold at a discount when the thrift is resolved. For sample thrifts, total net fixed assets are \$1.96 billion. We assume the discount on these assets is 10 percent, which gives us resolutionrelated costs associated with fixed assets of $\$ 0.20$ billion and prompt resolution costs of $\$ 7.64$ billion. Second, the 55 thrifts with positive $\mathrm{SNW}$ are assigned a zero cost of prompt resolution. Deducting the $\$ 185$ million in $\mathrm{SNW}$ in these thrifts (see table IV) from the sample total gives a prompt resolution cost of $\$ 7.66$ billion.

Finally, we need to make an adjustment to SNW to account for administrative and legal costs associated with closing and resolving the forbearance thrifts. We therefore deduct 0.5 percent of total assets from the SNW estimate. We arrive at a cost of 0.5 percent by dividing the insurance settlement and administrative expenses for FSLIC in 1985 and 1986 reported by the U.S. GAO (1987b) by total failed thrift assets in 1985 and 1986 reported in Barth (1991, table 3-2). The total projected administrative costs associated with prompt resolution and the estimated cost of prompt resolution are $\$ 0.7$ billion and $\$ 8.36$ billion. ${ }^{18}$

\footnotetext{
${ }^{17}$ Because we use a version of the Kane-Yu formula that does not fully take into account prepayment when calculating synthetic market values for the mortgage and mortgage-backed security portfolios, our estimates of SNW are likely to overstate the size of the losses (understate the true market net worth).

${ }^{18}$ We do not adjust prompt resolution costs to take into account the value of thrift charters. In cases where the FSLIC or RTC sells the insured deposits or resolves the failed thrift by selling it (often net of problem assets) to another depository institution or investor group, any purchase premium paid reflects the residual value of the thrift as an ongoing concern, or rather its charter value. However, Kane and Unal (1990) and Thomson $(1987,1992)$ argue that one component of charter value is the capitalized value of future deposit insurance subsidies. To the extent that the purchase premium reflects the capitalized value of future subsidies, it should
} 


\section{Estimates of Future Resolution Costs}

To estimate future resolution costs, we tracked all 952 thrifts from December 1979 through

July 1992. We used the Office of Thrift Supervision's (OTS) merger history file, various issues of Thomson Savings Directory (formerly Rand McNally's, The U. S. Savings

Institutions Directory), and lists of FSLIC-insured (FDIC-SAIF insured) thrift institutions that were closed between January 1, 1980 and July 31, 1992 from Barth et al. (1989) and from the RTC. $^{19}$

The 952 forbearance thrifts can be divided into four general categories: independent and still operating as of July 31,1992 ; in RTC conservatorship as of July 31,1992 ; merged into another thrift; or closed. This sample of thrifts breaks down as follows: 186 are still operating as independent institutions, 194 merged into an ongoing independent thrift, and 11 were acquired by banks. Nine sample thrifts are currently in RTC conservatorship, and another 20 merged into a thrift currently in RTC conservatorship. The remaining 532 thrifts either failed outright or merged into a thrift that was subsequently closed: 361 were closed directly, 68 merged into another forbearance thrift before it was closed, and the remaining 103 merged into a non-sample thrift that was later closed. ${ }^{20}$

not be viewed as reducing FSLIC resolution costs.

${ }^{19}$ We are indebted to Robert Grohol of the RTC for providing us with the list of RTC resolutions (including resolution costs) and with the list of RTC conservatorships through the end of 1991. We are also indebted to Steve Watson of the OTS for providing us with the merger history file. Information on RTC resolutions and conservatorships for 1992 was obtained from the RTC Review and from the corporation's press releases.

${ }^{20}$ Of the 34 thrifts that were dropped from the sample because they were merged out of existence in 1980 , 13 merged into currently ongoing (as of June 30,1992) thrifts, two merged into thrifts now in RTC conservatorship, and 19 merged into thrifts that were subsequently closed. 
For thrifts that were closed or were sold off with federal assistance from 1980 through 1988, the estimated resolution cost to the FSLIC at the time of closing is obtained from Barth, Bartholomew, and Bradley (1989, appendix I-9). Estimated resolution costs to the RTC at the time of closing for thrifts closed from January 1, 1989 through July 31, 1992 are obtained from the RTC.

The FSLIC and RTC resolution costs are estimates of the total cost of resolving the thrift made at the time of closing. A recent paper by Blalock, Curry, and Elmer (1991) suggests that at least the FSLIC estimates significantly understate actual resolution costs: Between 1984 and 1987, these costs were understated on average by 26 percent. For thrifts resolved through liquidation, FSLIC estimates were even worse, undershooting actual resolution costs on average by 35.3 percent.

A second source of bias in these estimates is that they are costs to the FSLIC and therefore do not include the value of tax benefits the FSLIC may have passed on to acquirers. Barth, Bartholomew, and Elmer (1989) find that for resolutions done in 1988, each dollar of tax benefits passed on to an acquirer of a failed thrift lowered the FSLIC's resolution cost by

98 cents. However, in such deals, the total cost to taxpayers is higher by the amount of these tax benefits, and reported costs to the FSLIC may understate total resolution costs by as much as 13 percent (see Blalock, Curry, and Elmer). Therefore, the use of FSLIC resolution cost estimates biases us against accepting the null hypothesis.

\section{Closed Institutions}

For the 361 forbearance thrifts that were closed as independent institutions, direct 
estimates of the resolution costs amount to $\$ 49.744$ billion. However, this number is misleading when evaluating forbearance because it does not take into account the time value of money. Therefore, we discount these resolution costs back to June 30,1980 , using the nominal yield on equivalent maturity Treasury debt. As shown in table $\mathrm{V}$, we assume that closings take place evenly throughout the year; therefore, for discounting purposes, we assume all closures during the interval from January through December occur on June 30 . The present value of estimated resolution costs for these 361 closed thrifts is $\$ 20.34$ billion.

\section{Open Institutions}

Unfortunately for taxpayers, the costs associated with closed institutions are only a part of the total direct costs of forbearance. A large number of thrift institutions have yet to be closed by the OTS or resolved by the RTC. As of July $31,1992,186$ of our original sample thrifts were independent, ongoing institutions and another nine were operating under RTC conservatorship. All of the conservatorship institutions and a number of the independent open thrifts will require government intervention at a cost to the taxpayer.

Tables VI and VII present a breakdown of the 186 sample thrifts in private hands and the nine sample thrifts in conservatorship, respectively, by TNW as of July 31,1992 . For open thrifts, five institutions with a total of $\$ 6.51$ billion in assets and TNW of $-\$ 0.35$ billion had negative TNW. Another 12 thrifts with $\$ 6.94$ billion in assets had less than 2 percent TNWA, and thus failed to meet the minimum net worth requirement for continued operation in the prompt intervention rules established by Title III of the Federal Deposit Insurance Corporation Improvement Act of 1991 (FDICIA). Finally, 43 additional institutions with 
$\$ 27.89$ billion in assets had less than 4 percent TNWA and were therefore undercapitalized. ${ }^{21}$ Table VII shows that potential problems are obvious among conservatorship thrifts. This suggests that further problems remain, increasing the realized cost of forbearance to taxpayers. Moreover, problem assets (consisting of nonperforming loans and repossessed assets) on the books of these thrifts are 163 percent of TNW and more than 5 percent of total assets.

Using the RTC's loss experience of 27.4 percent of initial total assets for all resolved institutions from its inception through July 31,1992 , projected losses could be as high as $\$ 11.16$ billion (\$3.39 billion discounted back to June 1980 ) for 86 undercapitalized open thrifts and $\$ 2.28$ billion ( $\$ 0.70$ billion discounted value) for conservatorship thrifts. Using a more conservative estimate of 15 percent of total assets, projected losses would be $\$ 6.02$ billion and $\$ 1.25$ billion ( $\$ 1.85$ billion and $\$ 0.38$ billion discounted value) for open and conservatorship thrifts, respectively. A true projection of losses in unresolved nonviable thrifts would require a two- or three-step procedure as in Barth, Bartholomew, and Bradley (1990). ${ }^{22}$ However, the estimates in this paper highlight the fact that a nontrivial part of the cost of forbearance is represented by embedded losses in yet-to-be-resolved insolvent thrifts.

\footnotetext{
${ }^{21}$ FIRREA (1989) mandates that savings and loan institutions' capital requirements be no less stringent than those of national banks. FIRREA mandates minimum capital standards for savings and loan institutions of 1.5 percent TNWA and 3 percent GAAP net worth to total assets. However, the actual capital requirement in FIRREA turned out to be more stringent than the language indicates, because in addition to these two minimum capital rules, the statute mandates that thrift capital requirements be no less stringent than those for national banks. Except for banks that garner the top rating on their last bank examination, the minimum leveraging requirement for national banks is 4 percent Tier 1 capital (which is essentially TNW) to total assets. Thrift capital standards are dealt with in Section 301 of FIRREA (1989, P. L. 101-73). For a discussion of bank capital standards, see Huber (1991, ch. 15).

${ }^{22}$ For a review of the literature on estimating resolution costs, see Bradley (1992).
} 


\section{$\underline{\text { Mergers }}$}

Accounting for losses associated with forbearance thrifts that are merged out of existence often requires a judgment call. In some cases it may be appropriate to allocate a portion of the resolution costs associated with an institution that acquired a sample thrift. An example is a supervisory merger, in which no direct assistance was provided, but the intent was to prevent the failure of the forbearance thrift. These cases are not treated as closures by the thrift regulators and are assumed to have been done at zero cost to the deposit insurance fund or to the RTC. However, Barth (1991) notes that in many of these deals, tax benefits were passed on to the acquirer and thus were costly to the taxpayer. Moreover, in a number of cases, especially as the financial condition of the FSLIC deteriorated, supervisory mergers were used as a way of delaying the recognition of losses as insolvent or marginally capitalized thrifts were merged into other weak institutions.

As reported in Barth (1991, table 3-2), of the 1,131 mergers that occurred between 1980 and 1988, 333 (29 percent) were supervisory mergers. Because we do not have information on whether a merger was a private or a supervisory merger, we treat all forbearance thrifts that are acquired by a nonsample thrift or bank as a private merger with zero resolution costs. This, of course, biases us against accepting the null hypothesis that forbearance was costly to taxpayers because, as noted earlier, supervisory mergers had real costs to the taxpayer even though FSLIC's reported loss was zero. ${ }^{23}$

23 Note, for example, that 103 forbearance thrifts were acquired by thrifts that eventually failed at a total cost of $\$ 30.61$ billion $(\$ 12.06$ billion discounted to June 30,1980 ). To the extent supervisory mergers were used as a loss delay mechanism, some portion of the $\$ 12$ billion present-value resolution cost is a direct cost of forbearance. 


\section{The Direct Cost of Forbearance}

As discussed earlier, the direct cost of forbearance is the difference between the cost of prompt resolution, which we define as government action to close market-value-insolvent institutions in 1980, and the present value of costs associated with closing thrifts in the future. Using Kane-Yu's method for computing synthetic net worth, along with some adjustments for bankruptcy costs, we arrive at a cost of prompt resolution of $\$ 8.36$ billion.

For the 361 sample thrifts that were resolved directly by the FSLIC or the RTC, the present value of estimated resolution costs is $\$ 20.34$ billion. In other words, the cost associated with just those thrifts already closed exceeds the estimated cost of prompt resolution by $\$ 11.98$ billion. In fact, it exceeds our estimated upper-bound prompt resolution cost of $\$ 14.71$ billion by $\$ 6.73$ billion. ${ }^{24}$ Moreover, a more complete accounting for losses would include the costs associated with supervisory mergers and the embedded losses in yetto-be-resolved forbearance thrifts, both of which would further increase the cost of forbearance. Clearly, forbearance was a losing proposition for taxpayers.

\section{Conclusion}

This paper explicitly looks at the forbearance bet taken by policymakers at the end of the 1970s. Forbearance is defined as the failure of regulators to enforce book capital standards at the end of 1979. By comparing the cost of prompt regulatory intervention (defined here as closure or reorganization of capital-deficient thrifts in 1980) with the estimated resolution cost

\footnotetext{
24 The upper bound of prompt resolution cost is obtained by deducting administrative and legal costs ( $\$ 0.7$ billion), as well as the loss on fixed assets ( $\$ 0.2$ billion) from our highest estimate, in absolute-value terms, of SNW.
} 
at the time of closure for closed thrifts, and with the unbooked losses in open thrifts that are likely to require regulatory intervention, we fail to reject the null hypothesis that forbearance was a bad bet for taxpayers.

This paper provides direct evidence that forbearance contributed to the ultimate loss to taxpayers from the resolution of the thrift insurance mess. In fact, their losses grew despite the dramatic downturn in interest rates after 1982, which was a necessary event for taxpayers to win the forbearance bet. This result is in contrast to those in Benston and Carhill (1992), which suggest that forbearance was not costly. 
Avery, R. B., T. Belton, and M. Goldberg, 1988, "Market Discipline in Regulating Bank Risk: New Evidence from the Capital Markets," Journal of Money, Credit, and Banking 20, pp. 597-610.

Barth, J. R., 1991, The Great Savings and Loan Debacle, Washington, D.C.: American Enterprise Institute.

Barth, J. R., and M. G. Bradley, 1989, "Thrift Deregulation and Federal Deposit Insurance," Journal of Financial Services Research 2 (August), pp. 231-259.

Barth, J. R., P. Bartholomew, and M. G. Bradley, 1989, "An Analysis of Thrift Institution Failure Costs," Research Paper 89-03, Office of Thrift Supervision (November).

Barth, J. R., P. Bartholomew, and M. G. Bradley, 1990, "Determinants of Thrift Institution Resolution Costs," Journal of Finance 45 (July), pp. 731-754.

Barth, J. R., P. F. Bartholomew, and P. J. Elmer, 1989, "The Cost of Liquidating Versus Selling Failed Thrift Institutions," Research Paper 89-02, Office of Thrift Supervision (November).

Bartholomew, P. F., 1991, "The Cost of Forbearance during the Thrift Crisis," Congressional Budget Office Staff Memorandum, Washington, D.C.: CBO (June).

Benston, G. J., and M. Carhill, 1992, "The Thrift Disaster: Myths and Realities," Proceedings of a Conference on Bank Structure and Competition, Federal Reserve Bank of Chicago (May, forthcoming).

Blalock, J. B., T. J. Curry, and P. J. Elmer, 1991, "Resolution Costs of Thrift Failures," FDIC Banking Review 4 (Spring/Summer), pp. 15-26.

Board of Governors of the Federal Reserve System, 1991, Microdata Reference Manual, vol. 3. Washington, D.C.: Board of Governors (December).

Bradley, M. G., 1992, "Empirical Analysis of the Thrift Crisis and Deposit Insurance Reform," Journal of the American Statistical Association (forthcoming).

Cole, Rebel, Joseph A. McKenzie, and Larry White, 1991, "Deregulation Gone Awry: Moral Hazard in the Savings and Loan Industry," Working Paper, New York University.

Congressional Budget Office, 1992, "The Economic Effects of the Savings and Loan Crisis," Washington, D.C.: CBO (January). 
DeGennaro, R. P., L. H. Lang, and J. B. Thomson, 1991, "Troubled Savings and Loan Institutions: Voluntary Restructurings Under Insolvency," Working Paper 9112, Federal Reserve Bank of Cleveland (August).

Demirgüc-Kunt, A., 1991, "Principal-Agent Problems in Commercial Bank Failure Decisions," Working Paper 9106, Federal Reserve Bank of Cleveland (April).

Hendershott, P. H., and E. J. Kane, 1991, "Causes and Consequences of the 1980s Commercial Construction Boom," Working Paper, Ohio State University (January).

Hendershott, P. H., and E. J. Kane, 1992, "Office Market Values During the Past Decade: How Distorted Have Appraisals Been?" Working Paper 92-68, College of Business, Ohio State University (July).

Huber, Stephen K., 1991, Bank Officer's Handbook of Government Regulation, 2nd edition (1991 Cumulative Supplement No. 1). Boston: Warren, Gorham \& Lamont.

Jensen, M. C., and W. H. Meckling, 1976, "Theory of the Firm: Managerial Behavior, Agency Costs, and Ownership Structure," Journal of Financial Economics 3, pp. 305-360.

Kane, E. J., 1985, The Gathering Crisis in Federal Deposit Insurance. Cambridge, MA: MIT Press.

Kane, E. J., 1986, "Appearance and Reality in Deposit Insurance Reform," Journal of Banking and Finance 10, pp. 175-188.

Kane, E. J., 1989a, The S\&L Insurance Mess: How Did It Happen? Washington, D.C.: The Urban Institute.

Kane, E. J., 1989b, "Changing Incentives Facing Financial Services Regulators," Journal of Financial Services Research 2 (September), pp. 265-274.

Kane, E. J., 1990, "Principal-Agent Problems in S\&L Salvage," Journal of Finance 45 (July), pp. 755-764.

Kane, E. J., 1991, "Economic Estimates of the 1986-1989 Time Profile of Taxpayer Losses in the S\&L Insurance Fund," Congressional Budget Office Project Report, with an appendix prepared by M. Yu. Washington, D.C.: Congressional Budget Office (February 18).

Kane, E. J., and H. Unal, 1990, "Modeling Structural and Temporal Variation in the Market's Valuation of Banking Firms," Journal of Finance 45 (March), pp. 113-136.

Kane, E. J., and M. Yu, 1992, "Measuring the True Profile of Taxpayer Losses in the S\&L Insurance Mess," Working Paper 92-53, College of Business, Ohio State University (May). 
Pauley, B., 1989, The Thrift Reform Program: Summary and Implications. New York: Salomon Brothers (April).

Pike, C. J., and J. B. Thomson, 1991, "The RTC and the Escalating Costs of the Thrift Insurance Mess," Economic Commentary (May 15), Federal Reserve Bank of Cleveland.

Pratt, Richard T., 1990, "Statement before the U.S. House of Representatives Committee on Banking, Finance, and Urban Affairs," New York: Merrill-Lynch (mimeograph, October 20).

Resolution Trust Corporation, 1992, RTC Review 3 (January), Washington, D.C.

Rudolph, P., 1989, "The Insolvent Thrifts of 1982: Where Are They Now?" AREUEA Journal 17 (Winter), pp. 450-462.

Shoven, J. B., S. B. Smart, and J. Waldfogel, 1992, "Real Interest Rates and the Savings and Loan Crisis: The Moral Hazard Premium," Journal of Economic Perspectives 6 (Winter), pp. 155-167.

The U.S. Savings Institutions Directory, editions 1982-1990. New York: Rand McNally.

Thomson Savings Directory, 1991 edition. Skokie, IL: Thomson Financial Publishing.

Thomson, J. B., 1987, "FSLIC Forbearances to Stockholders and the Value of Savings and Loan Shares," Economic Review (Quarter 3), Federal Reserve Bank of Cleveland, pp. 26-35.

Thomson, J. B., 1992, "Modeling the Bank Regulator's Closure Option: A Two-Step Logit Regression Approach," Journal of Financial Services Research 6, pp. 5-23.

United States General Accounting Office, 1987a, "Thrift Industry: Forbearance for Troubled Institutions 1982-1986," Briefing Report to the Chairman, Committee on Banking, Housing, and Urban Affairs, United States Senate, GAO (May).

United States General Accounting Office, 1987b, "Financial Audit: Federal Savings and Loan Insurance Corporation's 1986 and 1985 Financial Statements," Report to the Congress, GAO (May).

White, Lawrence J., 1991, The S\&L Debacle: Public Lessons for Bank and Thrift Regulation. New York: Oxford Press. 
Table I: Abbreviated Thrift Balance Sheet

\section{ASSETS}

\section{Mortgages}

VA

FHA-HUD

Conventional

Nonconforming loans and contracts

to facilitate the sale of REO

\section{Pass-through Mortgage-Backed Contracts}

Investment Securities

\section{Real Estate \\ Real estate held for investment \\ Other real estate owned}

\section{Other Loans \\ Commercial loans \\ Consumer loans}

\section{Mortgage-Servicing Rights}

\section{Service Corporation Subsidiaries}

All Other Assets

\section{LIABILITIES AND NET WORTH}

\section{FHLBB Advances}

Borrowings

Other borrowed money

Mortgages on association premises

Mortgage-backed bonds

Subordinated debt

Fixed-Rate Deposits

In certificates with denominations of

$$
\$ 100,000 \text { or more }
$$

In other accounts (earning in excess of the regular rate)

\section{Other Liabilities}

Non-interest-earning demand deposits and NOW accounts

NOW and passbook savings accounts (earning at or below the regular rate)

Escrow accounts

All other liabilities

(eaming at or below the regular rate)

Net Worth

Source: Authors. 
Table II: Sample Statistics

\begin{tabular}{|c|c|c|c|}
\hline SUBPORTFOLIO" & NET ASSETS & $\operatorname{ROA}^{c}$ & $\%$ OF ASSETS \\
\hline Mortgages & $114,951.93$ & 0.1016 & 78.48 \\
\hline Mortgage-Backed Securities & $5,317.13$ & 0.0803 & 3.63 \\
\hline Investments & $9,223.30$ & 0.1398 & 6.30 \\
\hline Other Loans & $4,689.88$ & 0.0948 & 3.20 \\
\hline Real Estate & 581.50 & NA & 0.40 \\
\hline Mortgage-Servicing Rights & NA & 0.0019 & NA \\
\hline Service Corp. Subsidiaries & 830.77 & 0.1042 & 0.57 \\
\hline FHLBB Advances & $12,476.13$ & 0.0805 & 8.52 \\
\hline Borrowings & $3,998.86$ & 0.0548 & 2.73 \\
\hline Fixed-Rate Deposits & $89,128.08$ & 0.1578 & 60.85 \\
\hline Slow Loans & $1,094.60$ & NA & 0.75 \\
\hline
\end{tabular}

Notes:

Number of observations in the sample is 952 .

NA - not applicable.

a) Includes all subportfolios for which synthetic market values are computed. Does not include other assets and other liabilities.

b) Mean subportfolio assets net of slow loans. Unit is thousands of dollars.

c) Mean ROA: retum on assets = subportfolio income divided by net assets.

d) Percent of total assets $=100$ times the ratio of mean subportfolio assets to mean total assets.

Sources: Federal Home Loan Bank Board, Thrift Financial Report; and authors' calculations. 
Table III: Unbooked Losses (Gains) in Asset and Liability Subportfolios, December 1979

\begin{tabular}{|c|c|c|c|}
\hline SUBPORTFOLIO & $\mathrm{BV}-\mathrm{MV}^{\mathbf{a}}$ & $\mathrm{PDR}^{\mathrm{b}}$ & $(\mathrm{BV}-\mathrm{MV}) / \mathrm{TNW}^{\mathrm{c}}$ \\
\hline Mortgages & $8,186.09$ & 0.0668 & 1.4503 \\
\hline Mortgage-Backed Securities & $1,307.70$ & 0.1432 & 0.2317 \\
\hline Investments & -232.38 & -0.1505 & -0.0412 \\
\hline Other Loans & 418.68 & 0.1059 & 0.0742 \\
\hline Real Estate & -61.38 & -0.1860 & -0.0109 \\
\hline Mortgage-Servicing Rights & -45.82 & NA & -0.0081 \\
\hline Service Corp. Subsidiaries & 333.19 & 0.4010 & 0.0590 \\
\hline FHLBB Advances & 542.29 & 0.0435 & 0.0961 \\
\hline Borrowings & 236.56 & 0.0592 & 0.0419 \\
\hline Fixed-Rate Deposits & $-4,630.53$ & -0.0494 & -0.8204 \\
\hline Slow Loans ${ }^{d}$ & 547.30 & 0.5000 & 0.0970 \\
\hline
\end{tabular}

Notes:

a) Unbooked loss on the subportfolio. Unit is thousands of dollars.

b) Pseudo-default rate $=$ unbooked gain or loss as a percent of subportfolio assets.

c) Unbooked loss on the subportfolio divided by tangible net worth.

d) Slow loans net of valuation allowances. Assumed loss rate on these assets is 50 percent.

Sources: Federal Home Loan Bank Board, Thrift Financial Report; and authors' calculations. 
Table IV: Sample Thrifts in December 1979 by Ratio of Synthetic Net Worth to Assets

\begin{tabular}{|c|c|c|c|}
\hline $\begin{array}{l}\text { SAMPLE } \\
\text { THRIFTS WITH }\end{array}$ & NUMBER & $\begin{array}{c}\text { TANGIBLE } \\
\text { NET WORTH' }\end{array}$ & $\begin{array}{c}\text { SYNTHETIC } \\
\text { NET WORTH }\end{array}$ \\
\hline $0.00<\mathrm{SNWA}^{b}$ & 55 & 295.778 & 185.017 \\
\hline$-0.05<\mathrm{SNWA} \leq 0.00$ & 293 & $1,884.561$ & $-1,408.647$ \\
\hline$-0.10<\mathrm{SNWA} \leq-0.05$ & 530 & $3,040.138$ & $-5,617.639$ \\
\hline$-0.15<$ SNWA $\leq-0.10$ & 70 & 153.384 & -531.288 \\
\hline SNWA $\leq-0.15$ & 4 & -0.400 & -70.639 \\
\hline TOTAL & 952 & $5,373.461$ & $-7,443.196$ \\
\hline
\end{tabular}

Notes:

a) Unit is millions of dollars.

b) Synthetic net worth to total assets.

Sources: Federal Home Loan Bank Board, Thrift Financial Report; and authors' calculations. 
Table V: Discounted Expected Resolution Costs for Closed Institutions, 1981-1992

\begin{tabular}{|c|c|c|c|c|}
\hline TIME OF CLOSING" & $n^{b}$ & $r^{c}$ & $\begin{array}{l}\text { RESOLUTION } \\
\text { COST }^{d}\end{array}$ & PV $\operatorname{COST}^{\circ}$ \\
\hline $1 / 1 / 81$ to $12 / 31 / 81$ & 1 & 0.1198 & 520 & 464 \\
\hline $1 / 1 / 82$ to $12 / 31 / 82$ & 2 & 0.1139 & 553 & 446 \\
\hline $1 / 1 / 83$ to $12 / 31 / 83$ & 3 & 0.1071 & 170 & 125 \\
\hline $1 / 1 / 84$ to $12 / 31 / 84$ & 4 & 0.1053 & 138 & 92 \\
\hline $1 / 1 / 85$ to $12 / 31 / 85$ & 5 & 0.1042 & 471 & 287 \\
\hline $1 / 1 / 86$ to $12 / 31 / 86$ & 6 & 0.1042 & 1,060 & 585 \\
\hline $1 / 1 / 87$ to $12 / 31 / 87$ & 7 & 0.1042 & 2,332 & 1,160 \\
\hline $1 / 1 / 88$ to $12 / 31 / 88$ & 8 & 0.1041 & 12,257 & 5,551 \\
\hline $1 / 1 / 89$ to $12 / 31 / 89$ & 9 & 0.1040 & 3,243 & 1,331 \\
\hline $1 / 1 / 90$ to $12 / 31 / 90$ & 10 & 0.1039 & 14,219 & 5,291 \\
\hline $1 / 1 / 91$ to $12 / 31 / 91$ & 11 & 0.1035 & 12,801 & 4,333 \\
\hline $1 / 1 / 92$ to $6 / 30 / 92$ & 12 & 0.1032 & 2,207 & 679 \\
\hline
\end{tabular}

Notes: $P V($ Resolution Cost $)=(\text { Estimated Resolution Cost in year } n)^{*} 1 /(1+r)^{n}$

a) Future time period in which thrift was closed.

b) Number of periods to discount back.

c) Discount rate for payment $\mathrm{n}$ periods into the future. From table 1.36, "Interest Rates and Capital Markets," Federal Reserve Bulletin (March 1979), p. A27.

d) Estimated resolution cost at time of closing. Unit is millions of dollars.

e) Present-value cost on June 30,1980 . Unit is millions of dollars.

Sources: Barth, Bartholomew, and Bradley (1989); Resolution Trust Corporation case files and press releases; RTC Review; and authors' calculations. 
Table VI: Condition of Open Sample Thrifts on July 31, 1992

\begin{tabular}{|c|c|c|c|c|}
\hline $\begin{array}{l}\text { OPEN SAMPLE } \\
\text { THRIFTS WITH" }\end{array}$ & NUMBER & ASSETS $^{b}$ & $\begin{array}{l}\text { TANGIBLE } \\
\text { NET WORTH }\end{array}$ & $\begin{array}{c}\text { PROBLEM } \\
\text { ASSETS }^{b}\end{array}$ \\
\hline $0.05<\mathrm{TNWA}^{\mathrm{c}}$ & 86 & $31,453.794$ & $2,560.962$ & $1,262.906$ \\
\hline $0.04<$ TNWA $\leq 0.05$ & 40 & $26,314.068$ & $1,192.289$ & 889.084 \\
\hline $0.03<$ TNWA $\leq 0.04$ & 29 & $21,936.661$ & 783.500 & $1,181.047$ \\
\hline $0.02<$ TNWA $\leq 0.03$ & 14 & $5,595.887$ & 143.013 & 328.624 \\
\hline $0.01<\mathrm{TNWA} \leq 0.02$ & 7 & $5,681.919$ & 83.334 & 324.782 \\
\hline $0.00<\mathrm{TNWA} \leq 0.01$ & 5 & $1,257.521$ & 7.662 & 63.333 \\
\hline TNWA $<0.00$ & 5 & $6,512.003$ & -350.506 & 159.183 \\
\hline TOTAL & 186 & $97,494.332$ & $4,420.254$ & $4,208.959$ \\
\hline
\end{tabular}

Notes:

a) Data are from the December 31, 1991 Thrift Financial Report.

b) Unit is millions of dollars.

c) Tangible net worth to total assets.

Sources: Office of Thrift Supervision, Thrift Financial Report; and authors' calculations. 
Table VII: Condition of Sample Thrifts in RTC Conservatorship on July 31, 1992

\begin{tabular}{|c|c|c|c|c|}
\hline $\begin{array}{l}\text { CONSERVATORSHIP } \\
\text { THRIFTS WITH" }\end{array}$ & NUMBER & ASSETS $^{b}$ & $\begin{array}{l}\text { TANGIBLE } \\
\text { NET WORTH' }\end{array}$ & $\begin{array}{r}\text { PROBLEM } \\
\text { ASSETS }^{b}\end{array}$ \\
\hline $0.00<\mathrm{TNWA}^{\mathrm{c}}$ & 1 & $5,459.726$ & 7.693 & $1,670.290$ \\
\hline$-0.01<\mathrm{TNWA} \leq 0.00$ & 2 & 374.803 & -0.430 & 57.139 \\
\hline$-0.02<\mathrm{TNWA} \leq-0.01$ & 1 & 78.708 & -1.064 & 23.554 \\
\hline$-0.03<\mathrm{TNWA} \leq-0.02$ & 2 & 960.766 & -24.217 & 80.930 \\
\hline$T N W A \leq-0.03$ & 7 & $1,428.387$ & -220.596 & 205.397 \\
\hline TOTAL & 9 & $8,302.390$ & -238.614 & $2,037.310$ \\
\hline
\end{tabular}

Notes:

a) Data are from the December 31, 1991 Thrift Financial Report.

b) Unit is millions of dollars.

c) Tangible net worth to total assets.

Sources: Office of Thrift Supervision, Thrift Financial Report; and authors' calculations. 
Appendix A

Computations of the Minimum Capital Requirement for Thrifts

The capital requirement for thrifts in 1979 was

where

$$
\text { RAPNW } \geq \operatorname{Max}[\mathrm{MNWFIR,} \mathrm{MNWACI}]
$$

MNWFIR = minimum net worth by the federal insurance reserve test, .

MNWACI = minimum net worth by the asset composition test.

The MNWFIR comprises the applicable federal insurance reserve, plus 20 percent of scheduled items, plus 5 percent of the principal amount of unsecured borrowing (excluding borrowings from Federal Home Loan Banks and state-chartered central reserve institutions) with an original stated maturity greater than one year. The federal insurance reserve is computed as a percent of deposit liabilities, which increases with the number of years the institution has been in operation (beginning with 0.5 percent for two years and increasing by 25 basis points each year to a maximum of 5 percent).

The MNWACI is a risk-adjusted capital standard in which asset and liability categories have the following net worth requirements:

First mortgage loans and contracts:

Insured or guaranteed loans: $2 \%$

Conventional mortgage loans on one- to four-family dwellings: $5 \%$

Conventional mortgage loans on multifamily dwellings ( $>4): 5 \%$

Conventional mortgage loans on other improved real estate: $6 \%$

Conventional mortgage loans on developed lots and sites: $7 \%$

Conventional mortgage loans on land (undeveloped and for acquisition and development): $8 \%$

Nonconforming mortgage loans and contracts to facilitate the sale of real estate: $8 \%$

Other loans:

Insured or guaranteed loans for property alteration or repair: $3 \%$

Other loans for property alteration or repair: $5 \%$

Insured or guaranteed educational loans: $2 \%$

Other educational loans: $6 \%$

Insured or guaranteed mobile home or chattel paper: $3 \%$

Other mobile home or chattel paper: $3 \%$ 


\section{Formulae for Net Worth Requirements}

$$
\begin{aligned}
\text { MNWFIR = } & \text { SVGL3261 + 0.20*[SVGL0697 + SVGL0070 + SVGL0703 + SVGL0706 + SVGL0709 + } \\
& \text { SVGL0712 + SVGL0715 + SVGL0718 + SVGL0721 + SVGL0724 + SVGL0727 + } \\
& \text { SVGL0730 + SVGL0733 + SVGL0736 + SVGL 0739 + SVGL0742 + SVGL0745 + } \\
& \text { SVGL0748 + SVGL0751 + SVGL0754 + SVGL0757 + SVGL0760 + SVGL0763 + } \\
& \text { SVGL0766 + SVGL0769 + SVGL0772 + SVGL0775 + SVGL0796 + SVGL0778 + } \\
& \text { SVGL0781 + SVGL0784 + SVGL0787 + SVGL0790] + 0.05*SVGL2658. }
\end{aligned}
$$

MNWACI $=0.02 *($ SVGL1436 + SVGL1437 + SVGL1438 + SVGL1439 + SVGL1465 + SVGL1441 + SVGL1442 + SVGL1443 - SVGL1454 + SVGL1462 + SVGL1455 + SVGL1481) + $0.03 *$ (SVGL2055 + SVGL0857 + SVGL0858 + SVGL2036 + SVGL0853 + SVGL0854 + SVGL0855 + SVGL0872) + 0.05*(SVGL1444 + SVGL1446 + SVGL2056 + SVGL2130) + $0.06 *($ SVGL1470 + SVGL1448 + SVGL1463 + SVGL2039 + SVGL1991 + SVGL1468 + SVGL1469) + 0.07*(SVGL1447 + SVGL1493 - SVGL1498 - SVGL1497) + 0.08*(SVGL1449 + SVGL1451 + SVGL1452 + SVGL1453 - SVGL1457) + 0.10*(SVGL1467 + SVGL1483 + SVGL0859 - SVGL1482 - SVGL1492 - SVGL1491) + .05*SVGL2658.

Certain aggregation problems are associated with the construction of the asset composition index (ACI). When approximations were necessary, we intentionally constructed the index so that it would understate the true ACI. This causes us to undersample thrifts not meeting capital requirements, but we omit only those that are very close to meeting the requirements. Our ACI differs from the true $\mathrm{ACI}$ in the following ways:

a) MNWACI should include $0.15^{*}$ (unsecured consumer loans). However, we cannot get a separate item for this because it is included in SVGL1991. Therefore, it is implicitly weighted at 0.06 in MNWACI.

b) Other nonconsumer loans, SVGL1469, is not included in any of the asset categories. We include it in the MNWACI at a 0.06 weight (the same weight as secured consumer loans).

c) Accrued interest is added at the minimum weight for the asset category. Depreciation and valuation allowances are subtracted at the maximum weight for the asset category. The weights are as follows:

Accrued interest:

Mortgage loans: SVGL1455 (weight 0.02)

Other loans: SVGL1481 (weight 0.02)

Valuation allowance:

Mortgage loans: SVGL1457 (weight 0.08)

Other loans: SVGL1482 (weight 0.10 )

Real estate loans: SVGL1492 (weight 0.10)

Other real estate: SVGL1498 (weight 0.07) 


\section{Depreciation allowance:}

Real estate: SVGL1491 (weight 0.10).

Other real estate: SVGL1497 (weight 0.07).

The SVGL items are from the FHLBB Management Information System Semiannual Financial Report, commonly known as the Thrift Financial Report. See the report's glossary for definitions of specific SVGL items. 
Appendix B

Composition of Thrift Asset and Liability Subportfolios

\section{Mortgages}

MLN =

SVGL0902 + SVGL1444 + SVGL1446 + SVGL1470 + SVGL1447 +

SVGL1448 + SVGL1449 + SVGL1451+ SVGL1452 + SVGL1453 - SVGL0695

- SVGL0698 - SVGL0701 - SVGL0704 - SVGL0707 - SVGL0710 - SVGL0713

- SVGL0716 - SVGL0719 - SVGL0722 - SVGL0725 - SVGL0728 - SVGL0731

- SVGL0734 - SVGL0737 - SVGL3067 - SVGL0767 - SVGL0770

Mortgage-Backed and Pass-Through Contracts

MBS $=$ SVGL1454 - SVGL0779

Investment Securities

SEC $=$ SVGL0851 + SVGL0854 - SVGL0782

Other Loans

OLN $=$ SVGL1467 + SVGL1458 + SVGL2055 + SVGL2056 + SVGL1462 + SVGL1463 + SVGL1468 + SVGL2036 + SVGL2039 + SVGL1991 + SVGL1469 - SVGL0740 - SVGL0743 - SVGL0746 - SVGL0749 - SVGL0752 SVGL0755 - SVGL0758 - SVGL0761 - SVGL0764 - SVGL3068

Real Estate

REH $=$ SVGL2150 + SVGL1493 + SVGL1494 (real estate held)

REO $=$ SVGL1483 + SVGL1484 (repossessed real estate)

Service Corp. Subsidiaries

SCS $=\quad$ SVGL2130

Mortgage-Servicing Rights

MSR = SVGL0820 (balance of mortgages serviced for others)

FHLBB Advances

ADV1 = SVGL2651 (advances $<1$ year)

ADV2 $=$ SVGL.2652 (advances $>1$ year)

Borrowings

OBM1 = SVGL2653 + SVGL2654 + SVGL2657 (other borrowed money < 1 year)

OMB2 $=$ SVGL2658 (other borrowed money $>1$ year)

OMB3 = SVGL2659 (mortgages on association premises)

$\mathrm{MBB}=\quad$ SVGL0850 (mortgage-backed bonds)

SUB $=$ SVGL3200 (subordinated debt) 
Fixed-Rate Deposits

FRD $=$ SVGL6645 + SVGL6647

Slow Loans

SLWLN $=0.2 *[$ SVGL0697 + SVGL0700 + SVGL0703 + SVGL0706 + SVGL0709 + SVGL0712 + SVGL0715 + SVGL0718] + SVGL0721 + SVGL0724 + SVGL0727 + SVGL0730 + SVGL0733 + SVGL0736 + SVGL0739 + SVGL0742 + SVGL0745 + SVGL0748 + SVGL0751 + SVGL0754 + SVGL0757 + SVGL0760 + SVGL0763 + SVGL0766 + SVGL0769 + SVGL0772 + SVGL0781 + SVGL0784

Tangible Net Worth

TNW $=$ SVGL3339-SVGL0868 - SVGL0869-SVGL0871

Formulae for Book Return on Asset Subportfolios

$\mathrm{MLN}_{\mathrm{i}}=$ SVGL4031 + SVGL4041 + SVGL4038 + SVGL4033 + SVGL4034 + SVGL 1455*[MLN/(MLN + MBS)] + SVGL0870*(0.1199)*[MLN/(MLN + SVGL0820)]

$\mathrm{MBS}_{\mathrm{i}}=\mathrm{SVGL} 4032+\mathrm{SVGL} 1455^{*}[\mathrm{MBS} /(\mathrm{MLN}+\mathrm{MBS})]$

$\mathrm{SEC}_{\mathrm{i}}=(\mathrm{SVGL} 4037+\mathrm{SVGL} 0852+\mathrm{SVGL0855}) / \mathrm{SEC}$

$\mathrm{OLN}_{\mathrm{i}}=(\mathrm{SVGL} 4036+\mathrm{SVGL} 1481) / \mathrm{OLN}$

$\mathrm{MSR}_{\mathrm{i}}=$ SVGL4039/SVGL0820 + SVGL0870*(0.11990*[SVGL0820/(MLN+SVGL0870)] -.0025 (net mortgage servicing income)

$A D V_{i}=S V G L 4173 /($ SVGL2651 + SVGL2652)

$\mathrm{OMB}_{\mathrm{i}}=\mathrm{SVGL} 4177 /(\mathrm{SVGL} 2653$ + SVGL2654 + SVGL2657 + SVGL2658 + SVGL2659)

$\mathrm{MBB}_{\mathrm{i}}=$ SVGL4175/SVGL0850 (if SVGL0850 >0, zero otherwise)

SUB $_{i}=$ SVGL4200/SVGL3200 (if SVGL3200 >0, zero otherwise)

$\mathrm{FRD}_{i}=\mathrm{SVGL4163/( \textrm {SVGL } 6 6 4 5 + \text { SVGL6647) }}$ 


\begin{tabular}{|c|c|c|c|}
\hline SUBPORTFOLIO & $r^{\circ}$ & $\mathrm{m}^{\mathrm{b}}$ & SOURCE \\
\hline Mortgages & 0.1164 & 12 & $\begin{array}{l}\text { FHLBB primary market series of average effective interest rates } \\
\text { on loans closed for December } 1979 \text {, assuming prepayment at the } \\
\text { end of } 10 \text { years. From table } 1.55 \text {, "Mortgage Markets," Federal } \\
\text { Reserve Bulletin (March 1980), p. A40. }\end{array}$ \\
\hline $\begin{array}{l}\text { Mortgage-Backed } \\
\text { Securities }\end{array}$ & 0.1135 & 12 & $\begin{array}{l}\text { Government National Mortgage Association secondary } \\
\text { market series of average net yields on a pool of } 30 \text {-year FHAVVA } \\
\text { mortgages, assuming prepayment in } 12 \text { years. See mortgage } \\
\text { subportfolio for reference. }\end{array}$ \\
\hline Investments & 0.1042 & 5 & $\begin{array}{l}\text { Five-year Treasury bond rate. From table 1.36, "Interest Rates: } \\
\text { Money and Capital Markets," Federal Reserve Bulletin (March } \\
\text { 1980), p. A27. }\end{array}$ \\
\hline Real Estate & 0.089 & 2 & $\begin{array}{l}\text { Average annual appreciation of commercial real estate for the U.S } \\
\text { during } 1978 \text { and } 1979 \text {. This rate is derived from table } 6-10 \text { in } \\
\text { White [1991]. }\end{array}$ \\
\hline Other Loans & 0.1412 & 5 & $\begin{array}{l}\text { Return on the loan portfolio for national banks. From Office of } \\
\text { Comptroller of the Currency, Annual Report, 1979, pp. B-19 and } \\
\text { B-22. }\end{array}$ \\
\hline $\begin{array}{l}\text { Mortgage-Servicing } \\
\text { Rights }\end{array}$ & 0.1164 & 12 & $\begin{array}{l}\text { Discounted at the same rate as the mortgage-backed } \\
\text { securities (MBS). See MBS portfolio for reference. }\end{array}$ \\
\hline $\begin{array}{l}\text { Service Corp. } \\
\text { Subsidiaries }\end{array}$ & 0.174 & NA & $\begin{array}{l}\text { Annual retum on the Standard \& Poor's } 500 \text { Stock Market Index } \\
\text { for } 1979 .\end{array}$ \\
\hline $\begin{array}{l}\text { FHLBB Advances } \\
(<1 \text { year }) \\
(>1 \text { year })\end{array}$ & $\begin{array}{l}0.1342 \\
0.1136\end{array}$ & $\begin{array}{l}1 / 2 \\
3.47\end{array}$ & $\begin{array}{l}\text { Six-month secondary market } C D \text { rate and effective yield on } \\
\text { three-year CDs (computed as the sum of the three-year Treasury } \\
\text { rate plus the six-month CD-T-bill spread). T-bill rates are } \\
\text { converted to an equivalent bond yield. From table 1.36, "Interest } \\
\text { Rates: Money and Capital Markets," Federal Reserve Bulletin } \\
\text { (March 1980), p. A27. Maturity information for FHLBB } \\
\text { advances is from Federal Home Loan Bank Board, Annual } \\
\text { Report, 1979, p. } 120 \text {. }\end{array}$ \\
\hline
\end{tabular}

\section{Borrowings}

$\mathrm{OBM}^{\circ}(<1$ year $)$

OBM ( $>1$ year)
$0.1342 \quad 1 / 2$

$0.1136 \quad 3.47$
Six-month secondary market $C D$ rate and effective yield on three-year CDs. Computation of rates, maturity assumptions, and sources are the same as for FHLBB advances. 


\begin{tabular}{|c|c|c|c|}
\hline $\begin{array}{l}\text { Mortgages on } \\
\text { Premises } \\
\text { Mortgage-Backed } \\
\text { Bonds }\end{array}$ & 0.1164 & 12 & $\begin{array}{l}\text { Government National Mortgage Association secondary market } \\
\text { series of average net yields on a pool of } 30 \text {-year FHA/VA } \\
\text { mortgages, assuming then-current rates and a } 12 \text {-year prepayment. } \\
\text { From table 1.55, "Mortgage Markets," Federal Reserve Bulletin } \\
\text { (March 1980), p. A40. }\end{array}$ \\
\hline Subordinated Debt & 0.1149 & 9 & $\begin{array}{l}\text { For subordinated debt, we use Moody's seasoned bond issue from } \\
\text { table 1.36, "Interest Rates: Money and Capital Markets," Federal } \\
\text { Reserve Bulletin (March 1980), p. A27. Maturity information for } \\
\text { subordinated debt is taken from Avery, Belton, and Goldberg } \\
\text { (1988). }\end{array}$ \\
\hline
\end{tabular}

Fixed-Rate Deposits $\quad 0.12042 \quad$ Two-year Treasury note yield plus the six-month CD-T-bill spread. From table 1.36, "Interest Rates: Money and Capital Markets," Federal Reserve Bulletin (March 1980), p. A27.

Notes:
a) The alternative market rate for the subportfolio used to construct synthetic market value. Market rates of return are average annual yields for December 1979.
b) Maturity of the subportfolio used in constructing the synthetic market value.
c) Other borrowed money. 


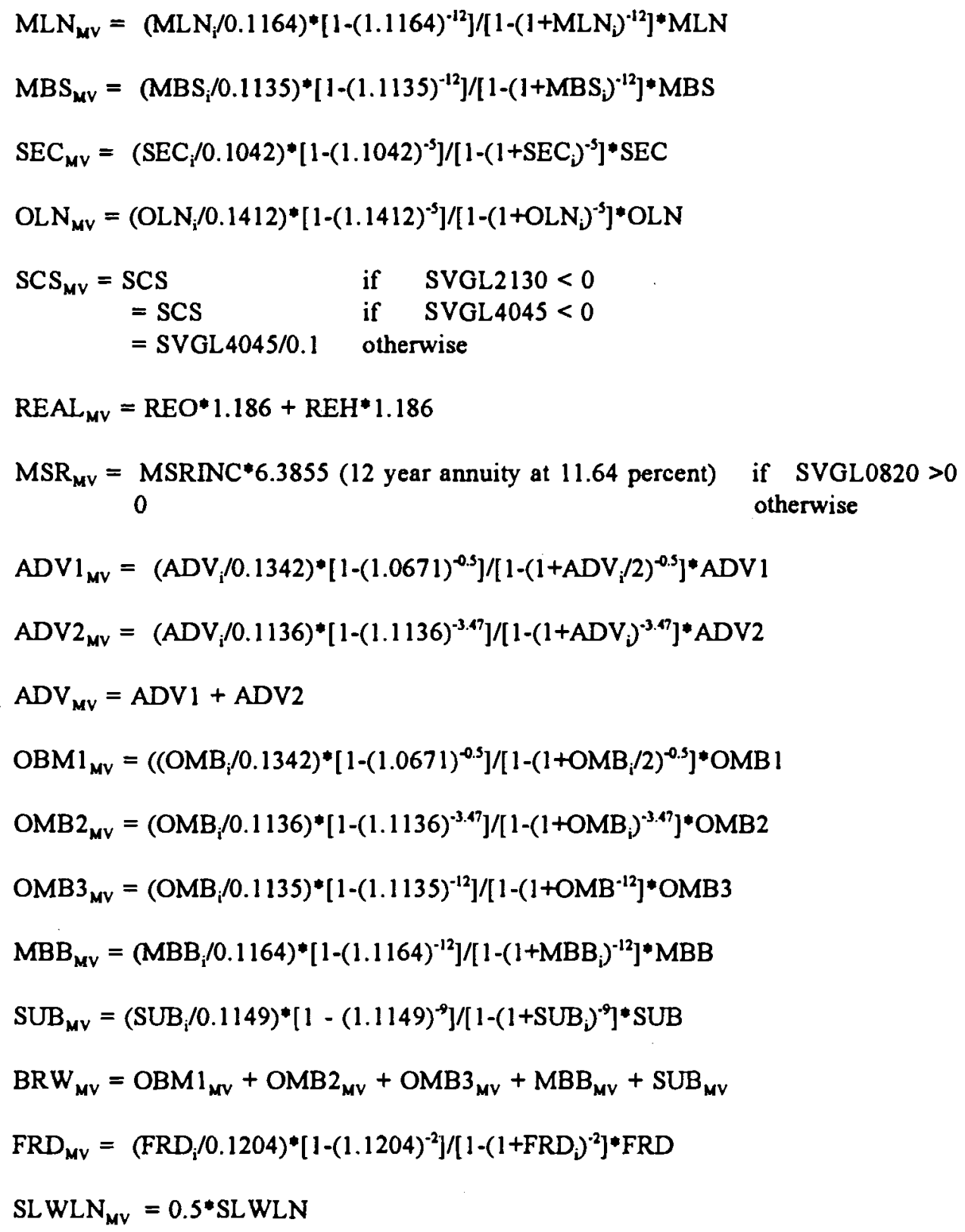

Notes: a) Market discount rates in the formulae are described in appendix $C$. 